Teknik, 38 (1), 2017, 21-27

\title{
Risk Assessment of Total Coliform in X WTP's Water Production Using Failure Mode and Effect Analysis Method
}

\author{
Bella A. Amanda*, Atiek Moesriati, Nieke Karnaningroem \\ Departemen Teknik Lingkungan, Fakultas Teknik Sipil, Lingkungan dan Kebumian, \\ Institut Teknologi Sepuluh Nopember, Kampus ITS Sukolilo, Keputih, Surabaya, Indonesia 60111
}

\begin{abstract}
Based on IPA Kedunguling testing report on March 2016, it is noted that the total coliform contained in the sample has exceeded the quality standard of Peraturan Menteri Kesehatan RI No 492/2010. The presence of total coliforms indicates water contamination by pathogen. Exceeding the quality standard means that the water is not safe to be consumed. The disinfection process has an importance rule in pathogen inactivation. Disinfectant performance is influenced by temperature, turbidity, $\mathrm{pH}$, and the presence of organic materials. The potential risks should be measured to determine causes of the problems and to find the appropriate risk reduction. The goal of this research is to control the quality of water by using a risk management approach Failure Modes and Effect Analysis (FMEA) methods. The risk assessment is using Risk Priority Number scale as a basis prioritization of remedial action on issues. Based on identification and risk analysis using FMEA, it is known that the greatest risks of failure are the stipulation of chlorine dose and organic substances in category of high risk level, residual chlorine in category of moderate risk level, and turbidity and $\mathrm{pH}$ in category very low risk level category. Some improvements that can be done to reduce total coliforms presence in IPA Kedunguling are by increasing residual chlorine to $0.6 \mathrm{mg} /$, by determining a daily chlorine level, by controlling DBPs forming through lowering the concentration of organic precursor using granular activated carbon $(G A C)$ or aeration, by lowering the dose of disinfectant, by separating DBPs after the compound is formed using GAC, by monitoring turbidity and $\mathrm{pH}$, and by washing the filters, regularly.
\end{abstract}

Keywords: FMEA; risk assessment; IPA Kedunguling; quality water production; RPN

\begin{abstract}
Abstrak
[Judul: Penilaian resiko Total Coliform dalam produksi air X WTP menggunakan metode failure dan analisis dampak] Laporan pengujian IPA Kedunguling pada Maret 2016 menunjukkan bawa kandungan coliform total pada sampel yang diuji melebihi standar kualitas yang ditetapkan Peraturan Menteri Kesehatan RI No 492/2010. Keberadaan coliform total menunjukkan kontaminasi air oleh pathogen yang berarti air tersebut tidak aman dikonsumsi. Proses disinfeksi memiliki peran penting dalam inaktivasi patogen. Kinerja desinfektan dipengaruhi oleh tempatur, kekentalan, pH, dan keberadaan material organik. Resiko potensial harus diukur untuk menentukan penyebab permasalahan dan menemukan cara paling tepat untuk mengurangi resiko. Penelitian ini bertujuan untuk mengontrol kualitas air dengan menggunakan pendekatan manajemen resiko Failure Modes and Effect Analysis (FMEA). Penilaian resiko dilakukan dengan menggunakan skala Risk Priority Number (RPN) sebagai dasar penentuan prioritas tindakan remedial atas masalah ini. Berdasarkan identifikasi dan analisis resiko menggunakan FMEA, diketahui resiko kegagalan terbesar berupa penetapan dosis klorin dan zat organik dalam kategori resiko tingkat tinggi, klorin residual dalam kategori resiko tingkat sedang, kekentalan dan pH dalam kategori resiko tingkat rendah. Usulan perbaikan yang bisa dilakukan untuk mengurangi kandungan coliforms total dalam IPA Kedunguling adalah dengan meningkatkan klorin residual sampai $0.6 \mathrm{mg} / \mathrm{l}$, menetapkan tingkat klorin harian, mengontrol pembentukan DBPs dengan mengurangi konsentrasi material organik sebelumnya dengan menggunakan Granular Activated Carbon (GAC) atau aerasi, dengan mengurangi dosis desinfektan, menyisihkan DBP setelah senyawa terbentuk menggunakan GAC, monitoring kekentalan dan $\mathrm{pH}$ serta pembersihan filter secara berkala.
\end{abstract}

Kata kunci: FMEA; penilaian resiko; IPA Kedunguling; kualitas produksi air; RPN

\footnotetext{
${ }^{*}$ Penulis Korespondensi.

E-mail: bellapriliani@gmail.com
}

\section{Introduction}

Providing healthy drinking water, affordable, and safe for consumers should be free of microbes. 


\section{Teknik, 38 (1), 2017, 22}

Based on the raw water quality data from 2014-2015, the parameters that exceeded the quality standard PP 82 Tahun 2001 are the parameters Biological Oxygen Demand (BOD), Chemical Oxygen Demand (COD), Dissolved Oxygen,ammonia and nitrite. The concentration of ammonia, nitrite, and organic substances can be reduced through a series of pre-chlorination, coagulation, flocculation, sedimentation, filtration, and postchlorination so that it meets quality standards Permenkes RI No. 492 Tahun 2010. However based on mandatory examination reports parameters per 6 months of water distribution in 2014-2015 known that two samples exceeded the standard quality parameters of total coliform and one sample exceeded the standard quality parameters of E.Coli. Furthermore, the water production examinations in March 2016 note that the samples exceeded the standard quality parameters of total coliforms. The presence of total coliforms indicates water contamination by pathogens and decreased water quality (Alang, 2015). Water produced for the public should meet the quality standards of Permenkes No. 492 Tahun 2010.

Processing building in IPA X capable of removing pathogens with $>99,99$ percentage. Disinfection process plays an important role in eliminating pathogens and maintains the water quality for distribution to consumers (Gray, 2008).

WTP X raw water source comes from the Afvoer River contaminated by domestic and industrial waste around the river. Processing flow of WTP X can be seen in Figure 1.

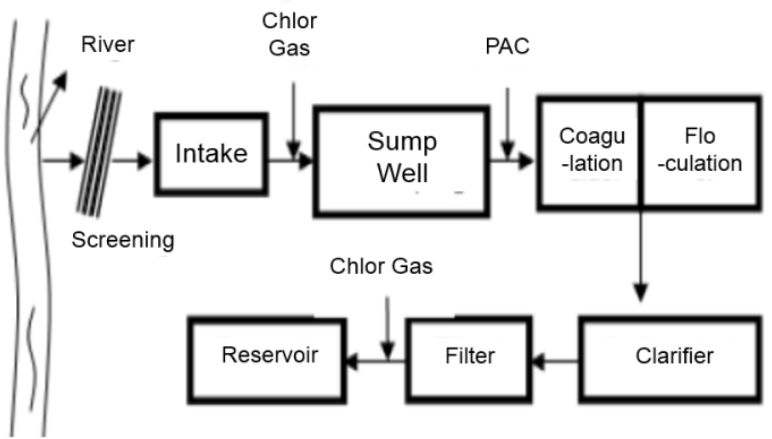

Figure 1. Processing Flow of WTP X

This paper focuses on identifying the risk caused by the presence of total coliforms in water production. Water production quality is controlled using a risk management approach to identify and measure potential risks in order to determine the risk from problem caused and appropriate risk reduction measures [3,4]. The risk assessment based on Risk Priority Number (RPN) scale are the occurrence frequency level (occurrence), severity, and detection level (detection) to seek the highest RPN value. RPN value is used as basis in determining the priority of corrective actions (Davison, et al., 2005).
There are two reservoirs to store the distributed water. Reservoir 1 stores the processed water from WTP 1 and WTP 2. Reservoir 2 stores the processed water from WTP 3 . This study focused on risk assessment on WTP 3 as seen in Figure 2.

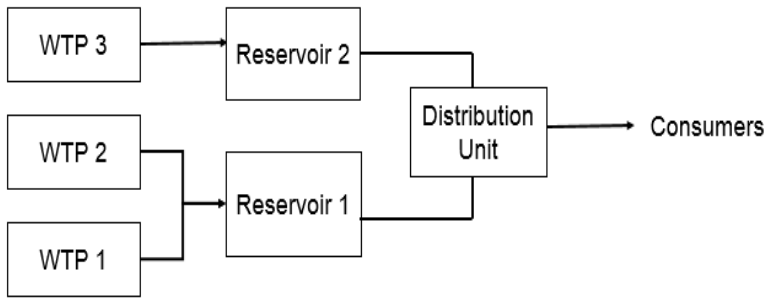

Figure 2. Production Flow of WTP X

\section{Materials and Methods}

Data used in the analysis of water quality production of WTP X are primary data gained from the observation and total coliform parameter sampling, residual chlorine, $\mathrm{pH}$, turbidity, and organic substances in the raw water, clarifier unit outlet, filter unit outlet, and the inlet reservoir. Analysis of water samples conducted at the Laboratory of Environmental Engineering and Science Laboratory ITS, and WTP X laboratory. Secondary data gathered from the production process, raw water quality, daily water production, and water distribution per 6 months.

Data processing is done by comparing data of produced water quality to the quality standards to identify problems of total coliform presence as the risk of deterioration in quality of water produced. The parameters related to risk caused by the presence of total coliforms are used as a parameter to be analyzed to identify the root causes.

To identify the problem, a fishbone diagram was made from the obtained data. This diagram describes the factors estimated to be the root of the problem.

Quality analysis of Produced Water used FMEA Method. Identifying the source of the problem and its effect on the processing system as the cause of the presence of total coliforms in water production. The analysis was carried on by "bottom-up", the examination of the production process from raw water to the water quality of production taking into account the causal relationships. Identified potential risks are assessed using a form of severity, occurrence, and detection. The output of the assessment is RPN value. The higher the value of the RPN, the risk of events become more critical and requires remedial action. Steps in applying FMEA method:

1. Identifying potential risk related to total coliform presence in produced water by testing water quality. Assessing severity value (S), occurency value (O), and detection value (D) on identified potential risks.

2. Counting RPN value using this following formula: 
Teknik, 38 (1), 2017, 23

RPN = severity $\mathrm{x}$ occurrence $\mathrm{x}$ detection

3. Determining risks level based on RPN value.

4. Provide a proposed improvement from highest to lowest risk level.

\section{Result and Discussion}

3.1 Water Quality Test Result

Water quality testing was conducte for nine days. Quality test results of raw water, clarifier, filter, and water production samples are listed in Table 1, Table 2, Table 3, and Table 4, respectively.

Table 1. Raw water quality testing report in the field

\begin{tabular}{ccccc}
\hline Sampling time & $\mathrm{pH}$ & $\begin{array}{c}\text { Temperature } \\
\left({ }^{\circ} \mathrm{C}\right)\end{array}$ & $\begin{array}{c}\text { Turbidity } \\
(\mathrm{NTU})\end{array}$ & $\begin{array}{c}\text { Organic matter } \\
(\mathrm{mg} / \mathrm{l})\end{array}$ \\
\hline $22 / 03 / 2016$ & 7,1 & 30,8 & 75,9 & 10,33 \\
$23 / 03 / 2016$ & 7,1 & 30 & 100 & 13,26 \\
$24 / 03 / 2016$ & 6,8 & 26,5 & 137 & 13,05 \\
$29 / 03 / 2016$ & 6,8 & 30,9 & 57 & 11,54 \\
$30 / 03 / 2016$ & 7,3 & 30,8 & 82,4 & 12,98 \\
$31 / 03 / 2016$ & 6,8 & 29,3 & 114 & 15,56 \\
$01 / 04 / 2016$ & 7,1 & 30,6 & 39,9 & 14,89 \\
$02 / 04 / 2016$ & 7,3 & 29,6 & 52,5 & 8,07 \\
$03 / 04 / 2016$ & 7,2 & 28,3 & 29,7 & 9,28 \\
average & $\mathbf{7 , 1}$ & $\mathbf{2 9 , 6 4}$ & $\mathbf{7 6 , 4 9}$ & $\mathbf{1 2 , 1 1}$ \\
\hline
\end{tabular}

Table 2. Clarifier water quality testing report in the field

\begin{tabular}{ccccccc}
\hline $\begin{array}{c}\text { Sampling } \\
\text { time }\end{array}$ & $\mathrm{pH}$ & $\begin{array}{c}\text { Tempe } \\
\text { rature } \\
\left({ }^{\circ} \mathrm{C}\right)\end{array}$ & $\begin{array}{c}\text { Turbidity } \\
(\mathrm{NTU})\end{array}$ & $\begin{array}{c}\text { Organic } \\
\text { matter } \\
(\mathrm{mg} / \mathrm{l})\end{array}$ & $\begin{array}{c}\text { Residual } \\
\text { chlorine } \\
(\mathrm{ppm})\end{array}$ & $\begin{array}{c}\text { Total } \\
\text { coliform } \\
(\mathrm{MPN} / 1 \\
00 \mathrm{ml})\end{array}$ \\
\hline $22 / 03 / 2016$ & 6,8 & 31,8 & 0,98 & 4,69 & 0,17 & 14 \\
$23 / 03 / 2016$ & 6,9 & 24,2 & 0,72 & 4,00 & 0,17 & 0 \\
$24 / 03 / 2016$ & 6,9 & 30,1 & 1,88 & 4,65 & 0,17 & 33 \\
$29 / 03 / 2016$ & 6,5 & 28,8 & 1,93 & 4,75 & 0,21 & 170 \\
$30 / 03 / 2016$ & 6,7 & 29,7 & 1,27 & 4,85 & 0,13 & 110 \\
$31 / 03 / 2016$ & 6,3 & 29,6 & 1,45 & 4,63 & 0,17 & 300 \\
$01 / 04 / 2016$ & 6,9 & 30,6 & 0,72 & 4,51 & 0,13 & 33 \\
$02 / 04 / 2016$ & 7,2 & 29 & 1,75 & 1,96 & 0,21 & 0 \\
$03 / 04 / 2016$ & 6,9 & 28,9 & 1,02 & 2,19 & 0,26 & 0 \\
average & $\mathbf{6 , 8}$ & $\mathbf{2 9 , 1 9}$ & $\mathbf{1 , 3 0}$ & $\mathbf{4 , 0 3}$ & $\mathbf{0 , 1 8}$ & $\mathbf{7 3 , 3 3}$ \\
\hline
\end{tabular}

Tabel 3. Filter water quality testing report in the field.

\begin{tabular}{ccccccc}
\hline $\begin{array}{c}\text { Sampling } \\
\text { time }\end{array}$ & $\mathrm{pH}$ & $\begin{array}{c}\text { Tempe } \\
\text { rature } \\
\left({ }^{\circ} \mathrm{C}\right)\end{array}$ & $\begin{array}{c}\text { Turbidity } \\
(\mathrm{NTU})\end{array}$ & $\begin{array}{c}\text { Organic } \\
\text { matter } \\
(\mathrm{mg} / \mathrm{l})\end{array}$ & $\begin{array}{c}\text { Residual } \\
\text { chlorine } \\
(\mathrm{ppm})\end{array}$ & $\begin{array}{c}\text { Total } \\
\text { coliform } \\
(\mathrm{MPN} / \\
100 \mathrm{ml})\end{array}$ \\
\hline $22 / 03 / 2016$ & 6,92 & 31,5 & 1,53 & 3,31 & 0,13 & 7 \\
$23 / 03 / 2016$ & 7,00 & 30,3 & 0,65 & 3,51 & 0,13 & 12 \\
$24 / 03 / 2016$ & 6,92 & 27,3 & 0,66 & 3,59 & 0,13 & 17 \\
$29 / 03 / 2016$ & 6,54 & 29,7 & 1,76 & 3,54 & 0,13 & 34 \\
$30 / 03 / 2016$ & 6,77 & 28,3 & 1,76 & 3,58 & 0,13 & 500 \\
$31 / 03 / 2016$ & 6,50 & 29,2 & 0,48 & 3,17 & 0,26 & 300 \\
$01 / 04 / 2016$ & 6,96 & 30,8 & 0,61 & 3,26 & 0,30 & 6 \\
$02 / 04 / 2016$ & 7,15 & 28,8 & 1,23 & 1,92 & 0,13 & 2 \\
$03 / 04 / 2016$ & 7,20 & 29,2 & 1,20 & 2,21 & 0,17 & 4 \\
Rata-rata & $\mathbf{6 , 8 8}$ & $\mathbf{2 9 , 4 6}$ & $\mathbf{1 , 1 0}$ & $\mathbf{3 , 1 2}$ & $\mathbf{0 , 1 7}$ & $\mathbf{9 8}$ \\
\hline
\end{tabular}

Tabel 4. Production water quality testing report in the field.

\begin{tabular}{ccccccc}
\hline $\begin{array}{c}\text { Sampling } \\
\text { time }\end{array}$ & $\mathrm{pH}$ & $\begin{array}{c}\text { Tempe } \\
\text { rature } \\
\left({ }^{\circ} \mathrm{C}\right)\end{array}$ & $\begin{array}{c}\text { Turbidity } \\
(\mathrm{NTU})\end{array}$ & $\begin{array}{c}\text { Organic } \\
\text { matter } \\
(\mathrm{mg} / \mathrm{l})\end{array}$ & $\begin{array}{c}\text { Residual } \\
\text { chlorine } \\
(\mathrm{ppm})\end{array}$ & $\begin{array}{c}\text { Total } \\
\text { coliform } \\
(\mathrm{MPN} \\
/ 100 \mathrm{ml})\end{array}$ \\
\hline $22 / 03 / 2016$ & 7,1 & 31,7 & 1,1 & 3,44 & 0,13 & 23 \\
$23 / 03 / 2016$ & 7,1 & 30,0 & 0,7 & 3,31 & 0,17 & 9 \\
$24 / 03 / 2016$ & 7,2 & 29,9 & 1,1 & 3,46 & 0,21 & 30 \\
$29 / 03 / 2016$ & 6,6 & 31,4 & 2,0 & 3,44 & 0,13 & 220 \\
$30 / 03 / 2016$ & 6,9 & 31,3 & 1,5 & 3,57 & 0,13 & 140 \\
$31 / 03 / 2016$ & 6,8 & 29,8 & 0,7 & 3,23 & 0,26 & 240 \\
$01 / 04 / 2016$ & 7,0 & 29,9 & 0,6 & 3,17 & 0,17 & 140 \\
$02 / 04 / 2016$ & 7,3 & 28,8 & 1,8 & 2,03 & 0,34 & 23 \\
$03 / 04 / 2016$ & 7,3 & 28,4 & 1,2 & 2,24 & 0,17 & 9 \\
average & $\mathbf{7 , 0}$ & $\mathbf{3 0 , 1}$ & $\mathbf{1 , 2}$ & $\mathbf{3 , 1 0}$ & $\mathbf{0 , 1 9}$ & $\mathbf{9 2 , 6 7}$ \\
\hline
\end{tabular}

\subsection{Identifying Risk Criteria}

Risk is focused on events that affect, obstruct, and cause disruption in water treatment operations, which led to total coliforms emergence in water production. The risk is influenced by the chlorination process. Chlorination performance is greatly influenced by the turbidity, organic substance, $\mathrm{pH}$, and residual chlorine. High organic substances trigger the formation of DBPs compound when reacting with chlorine. Risk criteria become the basis of risk assessment as an ideal condition to be achieved, as can be seen in Table 5 .

Table 5. Risk Criteria based on total coliform in produced water.

\begin{tabular}{|c|c|c|c|}
\hline No & Explanation & Standart Reference & $\begin{array}{c}\text { Ideal Conditions } \\
\text { Value }\end{array}$ \\
\hline 1 & Turbidity level & $\begin{array}{c}\text { EPA, } 2011 \text { and Permenkes } \\
492 / 2010\end{array}$ & $0-1,1 \mathrm{NTU}$ \\
\hline 2 & $\begin{array}{l}\text { Organic } \\
\text { Substances }\end{array}$ & Permenkes 492/2010 & $0-2,5 \mathrm{mg} / \mathrm{l}$ \\
\hline 3 & $\mathrm{pH}$ & Permenkes 492/2010 & $6,5-6,9$ \\
\hline 4 & $\begin{array}{l}\text { Residual } \\
\text { Chlorine }\end{array}$ & Permenkes 736/2010 & $0,82-1 \mathrm{ppm}$ \\
\hline 5 & Chlorine Dosing & SNI 6778:2008 & $\begin{array}{l}\text { Appropriate Chlorine } \\
\text { Dosing }\end{array}$ \\
\hline
\end{tabular}

3.3 Risk Identification

Risk identification is the process of determining what, why, and how a risk can occur so a system can be optimized through the risk prevention or risk reduction (Apsari dan Kamaningroem, 2014). Based on the analysis, some risk factors were listed using fishbone diagram to determine the root cause. The following fishbone analyze the presence of total coliforms in water production, as can be seen in Figure 3.

Fishbone diagram focused on the technical risk assessment on decreasing performance of disinfection units that considered having a major impact on total coliforms presence and causing water production does not meet quality standards. The disinfection unit serves as chemicals provider to reduce the organic substances in the raw water and kill germs/organism after pass through 
Teknik, 38 (1), 2017, 24

drinking water processor so residual disinfectant able to control the growth of pathogens during storage or distribution.

\section{Disinfection unit}

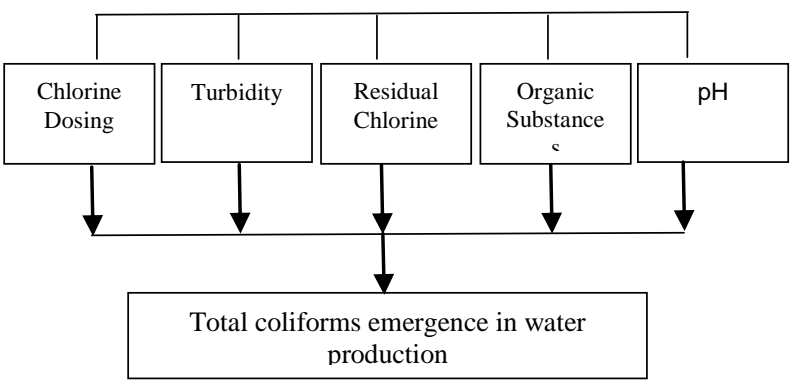

Figure 3. Fishbone Analysis

\subsection{Risk Analysis}

Criteria for assessment scale to 5 to set of the interval of each level so that an assessment becomes simpler to implement (Irawan, 2002). The following is a risk assessment of the total coliform in water production.

\subsubsection{Severity}

Severity is an assessment of the seriousness of the impact of potential failures. The greater the impact of a risk to the presence of total coliform in water production, then higher severity value (Amada, 2014). The amount of risk scale can be seen in Table 6 , Table 7 , Table 8 , Table 9, and Table10.

Table 6. Large scale of chlorine dosing risk

\begin{tabular}{|c|c|c|c|c|}
\hline \multicolumn{5}{|c|}{ Large Scale Risk of Chlorine Dosing Risk } \\
\hline 0 & 1 & 2 & 3 & 4 \\
\hline $\begin{array}{l}\text { Extra } \\
\text { Small } \\
\end{array}$ & Small & Average & Large & Extra Large \\
\hline \multicolumn{5}{|c|}{ Environmental Conditions Scale } \\
\hline 5 & 4 & 3 & 2 & 1 \\
\hline Very Good & Good & Moderate & Poor & Very Poor \\
\hline $\begin{array}{c}\text { Daily } \\
\text { dosing of } \\
\text { chlorine }\end{array}$ & $\begin{array}{l}\text { Once in } 3 \\
\text { days } \\
\text { chlorine } \\
\text { dosing }\end{array}$ & $\begin{array}{l}\text { Once in } 5 \\
\text { days } \\
\text { chlorine } \\
\text { dosing }\end{array}$ & $\begin{array}{l}\text { Once in } 7 \text { days } \\
\text { chlorine dosing }\end{array}$ & $\begin{array}{c}\text { No chlorine } \\
\text { dosing in }>9 \\
\text { days }\end{array}$ \\
\hline
\end{tabular}

Table 7. Large scale of residual chlorine risk

\begin{tabular}{|c|c|c|c|c|}
\hline \multicolumn{5}{|c|}{ Large Scale of Residual Chlorine Risk } \\
\hline 0 & 1 & 2 & 3 & 4 \\
\hline Extra Small & Small & Moderate & Large & Extra Large \\
\hline \multicolumn{5}{|c|}{ Enviromental Conditions Scale } \\
\hline 5 & 4 & 3 & 2 & 1 \\
\hline Very Good & Good & Moderate & Poor & Very Poor \\
\hline $0,82-1 \mathrm{mg} / \mathrm{l}$ & $\begin{array}{c}0,59-0,81 \\
\mathrm{mg} / \mathrm{l}\end{array}$ & $0,35-0,58 \mathrm{mg} / \mathrm{l}$ & $\begin{array}{c}0,11-0,34 \\
\mathrm{mg} / \mathrm{l}\end{array}$ & $\begin{array}{l}\leq 0,1 \mathrm{mg} / 1 \\
>1 \mathrm{mg} / \mathrm{l}\end{array}$ \\
\hline
\end{tabular}

Table 8. Large scale of turbidity risk

\begin{tabular}{ccccc}
\hline \multicolumn{5}{c}{ Large Scale of Turbidity Risk } \\
\hline 0 & 1 & 2 & 3 & 4 \\
Extra Small & Small & Moderate & Large & Extra Large \\
\hline \multicolumn{5}{c}{ Enviromental Conditions Scale } \\
\hline 5 & 4 & 3 & 2 & 1 \\
Very Good & Good & Moderate & Poor & $\begin{array}{c}\text { Very } \\
\text { Poor }\end{array}$ \\
$0-1,1$ NTU & $1,2-2,4$ & 2,5-3,7 NTU & $3,8-5$ NTU & $>5$ NTU \\
\hline
\end{tabular}

Table 9. Large scale of ph risk

\begin{tabular}{|c|c|c|c|c|}
\hline \multicolumn{5}{|c|}{ Lage Scale of pH Risk } \\
\hline 0 & 1 & 2 & 3 & 4 \\
\hline Extra Small & Small & Moderate & Large & Extra Large \\
\hline \multicolumn{5}{|c|}{ Enviromental Conditions Scale } \\
\hline 5 & 4 & 3 & 2 & 1 \\
\hline Very Good & Good & Moderate & Poor & Very Poor \\
\hline $\mathrm{pH} 6,5-6,9$ & $\mathrm{pH} 7,0-7,4$ & $\mathrm{pH} 7,5-7,9$ & $\mathrm{pH} 8,0-8,5$ & $\begin{array}{l}\mathrm{pH}>8,5 \\
\mathrm{pH}<6,5\end{array}$ \\
\hline
\end{tabular}

Table 10. Large scale of organic substance risk

\begin{tabular}{|c|c|c|c|c|}
\hline \multicolumn{5}{|c|}{ Large Scale of Organic Substance Risk } \\
\hline 0 & 1 & 2 & 3 & 4 \\
\hline Extra Small & Small & Moderate & Large & Extra Large \\
\hline \multicolumn{5}{|c|}{ Enviromental Conditions Scale } \\
\hline 5 & 4 & 3 & 2 & 1 \\
\hline Very Good & Good & Moderate & Poor & Very Poor \\
\hline $0-2,5 \mathrm{mg} / \mathrm{l}$ & $\begin{array}{c}2,6-5,1 \\
\mathrm{mg} / 1\end{array}$ & $5,2-7,7 \mathrm{mg} / \mathrm{l}$ & $7,7-10 \mathrm{mg} / 1$ & $>10 \mathrm{mg} / \mathrm{l}$ \\
\hline
\end{tabular}

The greater the scale of the environmental conditions, the smaller the value of the risk failure that occurred. Value scale environmental conditions are set to 5 as an ideal condition to be achieved. The example of chlorine residual risk severity ratings is as follows.

The residual chlorine average value $\quad=0,19 \mathrm{mg} / \mathrm{l}$

The scale of the current environmental conditions $=2$

The scale of the ideal environmental conditions $=5$

$$
\begin{aligned}
\text { Risk value } & =\frac{\text { The ideal environmental conditions scale-The current enviromental conditions scale }}{\text { The ideal environmental conditions scale }} \times 100 \% \\
& =\frac{5-2}{5} \times 100 \%=60 \%
\end{aligned}
$$

The results of calculation of the value of risk can be seen in severity criteria in Table 11 and Table 12 . 


\section{Teknik, 38 (1), 2017, 25}

Table 11. Criteria for determining severity

\begin{tabular}{clc}
\hline Value Range & \multicolumn{1}{c}{ Impact Severity Criteria } & Rank \\
\hline$\leq 20 \%$ & $\begin{array}{l}\text { Failure Form No Effect } \\
\text { Failure Form Affect the presence of total } \\
\text { coliform in water production } \\
\text { Causes a decrease in the performance of the } \\
\text { functions of the unit , and the effect on the } \\
\text { presence of total coliform in water production } \\
\text { Causing harm which would exceed the national } \\
\text { government regulatory standards and the } \\
\text { presence of total coliform in water production } \\
\text { Failure causes water produced can not be } \\
\text { consumed by the customer }\end{array}$ & 2 \\
\hline $81 \%$ & 4
\end{tabular}

Table 12. Severity scale on criteria environmental conditions

\begin{tabular}{clc}
\hline Range Value & \multicolumn{1}{c}{ Environmental Conditions Criteria } & Rank \\
\hline$\leq 20 \%$ & $\begin{array}{l}\text { Ideal conditions to be achieved , meets the } \\
\text { standards set limit } \\
\text { Water production meet the established } \\
\text { standards, could affect the performance of the } \\
\text { disinfection unit } \\
\text { Water production still meets the standards set } \\
\text { limits, affect the performance of the disinfection } \\
\text { unit }\end{array}$ & 2 \\
$41-60 \%$ & $\begin{array}{l}\text { Water production meets the standards set limits } \\
\text { but within the limits of minimum } \\
61-80 \%\end{array}$ & 4 \\
$>81 \%$ & $\begin{array}{l}\text { Water production does not meet the standards } \\
\text { set limit }\end{array}$ & 5 \\
\hline
\end{tabular}

The residual chlorine risk with $60 \%$ risk value fits into $3^{\text {rd }}$ rank with the criteria of the seriousness impact can cause a decreasing performance of unit functions and affect the presence of total coliform in water production as well as the criteria of the seriousness of the environmental conditions, water produced still meet the standards set, but influencing disinfection unit performance. Severity assessment results can be seen in Table 13.

Table 13. Severity value on failure risk

\begin{tabular}{lcc}
\hline \multicolumn{1}{c}{ Failure Type } & Range Value & Rank \\
\hline Residual Chlorine & 0,19 & 3 \\
$\mathrm{pH}$ & 6,88 & 1 \\
Organic Substance & 12,11 & 4 \\
Turbidity & 1,1 & 1 \\
Chlorine Dosing & Set the Chlorine Dosing $<9$ days & 4 \\
\hline
\end{tabular}

\subsubsection{Occurance}

Occurance is the calculated frequency or the cumulative number of failures that can occur (Amada, 2014). Scale occurance determination criteria can be seen in Table 14.

Table 14. Occurance criteria

\begin{tabular}{ccc}
\hline Rank & Risk Probability & Frequency \\
\hline 5 & Very Often & 9 events in 9 days \\
4 & Often & $7-8$ events in 9 days \\
3 & Fairly Often & $5-6$ events in 9 days \\
2 & Occasionally & $3-5$ events in 9 days \\
1 & Rare & $\leq 2$ events in 9 days \\
\hline
\end{tabular}

Examples Chlorine Residual risk severity ratings as follows:

Residual Chlorine range value $\quad=0,19 \mathrm{mg} / \mathrm{l}$

Range Value $\quad=0,11-0,34$

Frequency $\quad=9$ events

The calculation result of the risk value seen in the Table 14 are Chlorine Residual risk is at $5^{\text {th }}$ rank with a risk events probability often occur. Occurance assessment results can be seen in Table 15

Table 15. Occurance failure risks value

\begin{tabular}{lcc}
\hline \multicolumn{1}{c}{ Failure Type } & Frequency & Rank \\
\hline Residual Chlorine & 9 Events & 5 \\
$\mathrm{pH}$ & 3 Events & 2 \\
Organic Substance & 9 Events & 5 \\
Turbidity & 4 Events & 2 \\
Chlorine Dosing & 9 Events & 5 \\
\hline
\end{tabular}

\subsubsection{Detection}

Detection is measuring the ability to control failure that probably occur (Amada, 2014). Scale detection determination criteria can be seen in Table 16.

Table 16.2 Detection criteria

\begin{tabular}{cll}
\hline Rank & \multicolumn{1}{c}{ Detection Criteria } & $\begin{array}{c}\text { Based on Frequency } \\
\text { Events }\end{array}$ \\
\hline 5 & $\begin{array}{l}\text { Very high probability. Ineffective preventive } \\
\text { method, recurrent cause. }\end{array}$ & 9 events in 9 days \\
4 & $\begin{array}{l}\text { High probability. Ineffective preventive method, } \\
\text { recurrent cause. }\end{array}$ & 7-8 events in 9 days \\
3 & $\begin{array}{l}\text { Moderate probability. Ineffective preventive } \\
\text { method, recurrent cause. }\end{array}$ & $5-6$ events in 9 days \\
2 & $\begin{array}{l}\text { Low probability. } \\
\text { Very low probability. Effective preventive } \\
\text { method, no recurrent cause }\end{array}$ & $3-5$ events in 9 days \\
1 & &
\end{tabular}

A Higher risk level means the control method has lower ability to detect a failure risk, causing a very high probability of very high frequency of failure risk event. The example of detection assessment as below

The average value of chlorine residue $=0,19 \mathrm{mg} / \mathrm{l}$

The range value $\quad=0,11-0,34$

Frequency $=9$ events

Then the calculation result of risk value is seen in the value range of detection scale criteria based on the risk occurance in the Table 16, then we get the risk of chlorine residue in the $5^{\text {th }}$ level with a ineffective control or prevention method to detect failure risk event. It caused the probability of a risk to occur is very high and the potential cause of failure happened recurring. The complete result of detection assessment for another failure risk factor can be seen in Table 17 .

\subsection{Assesing Severity, Occurance, Detection}

FMEA is an analysis of failure potentials in scores, where scores were set by the expert team agreement (Fitria, 2009). Based on the calculation result of RPN number using the Equation 1, failure risks of total 


\section{Teknik, 38 (1), 2017, 26}

coliform in the water production can be seen in the Table 18.

Table 17. The detection value of failure risks

\begin{tabular}{lcc}
\hline \multicolumn{1}{c}{ Failure Type } & Frequency & Level \\
\hline Residual Chlorine & 9 event & 5 \\
pH & 0 event & 2 \\
Organic Substance & 7 event & 5 \\
Turbidity & 6 event & 3 \\
Chlorine Dosing & 9 event & 5 \\
\hline
\end{tabular}

Table 18. The calculation result of RPN number

\begin{tabular}{|c|c|c|c|c|c|c|c|}
\hline No & Unit & Failure & $\mathbf{S}$ & $\mathbf{O}$ & D & RPN & Priority \\
\hline \multirow{5}{*}{1} & \multirow{5}{*}{ Disinfection } & Chlorine residue & 4 & 5 & 5 & 75 & 3 \\
\hline & & $\mathrm{pH}$ & 1 & 1 & 1 & 4 & 5 \\
\hline & & $\begin{array}{l}\text { Organic } \\
\text { Substance }\end{array}$ & 2 & 4 & 4 & 100 & 2 \\
\hline & & Turbidity & 1 & 3 & 3 & 6 & 4 \\
\hline & & $\begin{array}{l}\text { Stipulation of } \\
\text { Chlorine Dosing }\end{array}$ & 4 & 5 & 5 & 100 & 1 \\
\hline
\end{tabular}

The RPN number in Table 18 is read in the determined scale of risk level in Table 19, to make it easier do the prority of recommended action.

Table 19. The determined scale of risk level

\begin{tabular}{lc}
\hline Risk level & Scale of RPN \\
\hline Very high & $101-125$ \\
High & $76-100$ \\
Moderate & $51-75$ \\
Low & $26-50$ \\
Very low & $\leq 25$ \\
\hline
\end{tabular}

Based on Table 19, it was known that the category of high risk level are the stipulation of chlorine dose and organic substance; the category of medium risk level is residual chlorine; the category of very low risk level are turbidity and $\mathrm{pH}$. Many number of risks happened can not be fixed at once, so determining the highest risk factor is necessary and required an immediate refinement. Risk assessment process is very important to determine the prority of recommended action (Davison et al., 2005).

\subsection{Proposed Improvements}

Identificating which processing part that gives the greatest risk, the assessment can be done to find solutions to reduce risks (Egerton, 1996). Listed here some proposed improvements that can be considered for WTP $\mathrm{X}$ from the highest risk level to the lowest risk.

a. Chlorine dosing risk

Determining dose of chlorine is done daily because the raw water quality has a fluctuating characteristic. The presence of total coliforms in water production showed that chlorine dosage given is not sufficient to left residual chlorine as a disinfectant.

b. Organic substance risk

During the water treatment process, unremoved organic substances will react with chlorine forming organic DBPs halogen precursors such as halogen trihalometan (THMs) and haloasetik acid (HAAs) which caused decreasing disinfectation effectiveness. In the first option, lowering concentration of organic substances can be done by applying aeration or activated carbon (granular activated carbon) (Departemen Pekerjaan Umum, 2007). Aeration process performed on the raw water or building additions on activated carbon (granular activated carbon) after the filtration unit, before the disinfection process. In the second option, lowering the dose of disinfectant can reduce the formation of DBPs. Consequently the contact time becomes longer. High dose disinfectant contain more amount and tighter than the lowest dose. Dense-structured particles will likely to frequently collide rather than the rare-structured particles so there are greater the possibility of reaction (Environmental Protection Agency, 2011) - (Brady, 1990). In the third option, the adsorption technology applied using granular activated carbon (GAC) before the produced water is distributed to the customer. GAC serves in eliminate particulate, colloidal, and dissolved organic carbon so that DBPs can be reduced and pathogenic microorganisms decreased (Farren, 2003).

c. Residual chlorine risk

The government does not set standards for water odor and taste, but by setting a maximum residual disinfectant concentration can avoid the physiological impact on health. Referring to Permenkes 736 Tahun 2010 the maximum residual chlorine in water produced is $1 \mathrm{mg} / \mathrm{l}$ and residual chlorine at the furthest point of distribution at least $0.2 \mathrm{mg} / \mathrm{l}$. Chlorination at a pipeline distribution network for streaming, which experienced a reduction (decay) due to reactions in the bulk water phase, reaction and corrosion of the pipe wall. Mathematical modeling is necessary to decrease residual chlorine to determine the residual chlorine dosing by the following equation

$$
\text { In } \mathrm{Ce}=\text { In } \mathrm{Co}-\left(\frac{k}{v}\right) L
$$

Where $\mathrm{Ce}$ is the residual Chlorine at a certain distance; $\mathrm{Co}$ is the Residual Chlorine concentration at $\mathrm{t}=0 ; \mathrm{k}$ is constant degradation; $\mathrm{v}$ is velocity $(\mathrm{m} / \mathrm{s})$, whereas $\mathrm{L}$ is the stream length $(\mathrm{m})$.

Based on the mathematical model, it is known that by providing residual chlorine of $0.6 \mathrm{ppm}$, at a farthest distribution of $2.99 \mathrm{~km}$, the concentration of residual chlorine meet Permenkes 36 Tahun 2010 which is $0.2 \mathrm{ppm}$. Residual Chlorine between 0.2-0.5 $\mathrm{ppm}$ can maintain the quality of the water from microbiological risks.

Increasing number of residual chlorine in water produced to $0.6 \mathrm{ppm}$ needs to be done to ensure the distributed water safe from total coliform risk. This concentration of chlorine as a disinfectant is still designated as safe for a drinking water. Here's a map 
Teknik, 38 (1), 2017, 27

of the distribution of WTP X associated with residual chlorine can be seen in Figure 4.

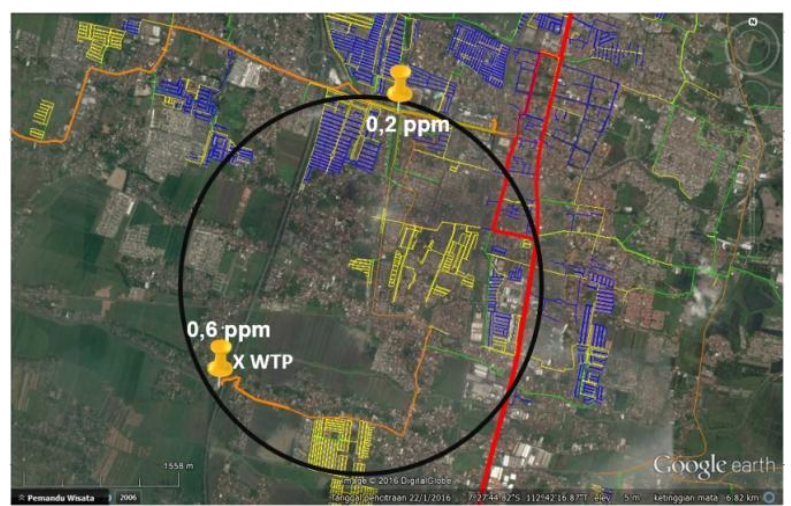

Figure 4. IPA X Distribution Map

d. Turbidity risk

Monitoring the operating system and washing the filter so that the results of the effluent remains at $<1.0 \mathrm{NTU}$ for optimal disinfection process. In addition, collecting data on washing filter (backwash) schedule, backwash duration, initial turbidity (after backwash) and final turbidity (before backwash). This data collection is part of the monitoring process to reach optimum disinfection unit performance.

e. $\mathrm{pH}$ risk

Monitoring filters operating system to maintain the effluent quality stays at 6.5-7.5 $\mathrm{pH}$ range, which provide more ideal environment for $\mathrm{HOCl}$ to formed.

\section{Conclusion}

Based on identification and risk analysis using FMEA, the parameters associated with the presence of total coliforms in WTP X water production is turbidity, organic substance, $\mathrm{pH}$, and temperature. The greatest failure risks in RPN value is chlorine dose and organic substance in high risk level, residual chlorine in moderate risk level, turbidity and $\mathrm{pH}$ in very low risk level.

Proposed improvements to reduce these risks are conducted by daily maintenance of chlorine dose, controlling the DBPs formation as a result of organic substances presence in water by lowering the concentration of organic substance using GAC or aeration technology, reducing the formation of DBPs by lowering disinfectant dose, set aside DBPs after forming using GAC, increasing the residual chlorine to $0.6 \mathrm{mg} / \mathrm{l}$, monitoring the filter system operation so that the results of the effluent remains at $<1.0 \mathrm{NTU}$ and $6.5-7.5 \mathrm{pH}$ level.

\section{Daftar Pustaka}

Alang, H. (2015). Deteksi coliform air PDAM di beberapa kecamatan Kota Makassar. in Seminar Nasional Mikrobiologi Kesehatan dan Lingkungan (pp. 16-20). Makassar: Fakultas Sains dan Teknologi Universitas Islam Negeri Alauddin.

Amanda, A.A. (2014) Business continuity plan pada teknologi dan sistem informasi BPR Bank Surya Yudha Banjarnegara. Surabaya: Departement of Information Systems ITS.

Apsari, M.N. and Karnaningroem, N. (2014). Analisis risiko dan optimasi kualitas air produksi Instalasi Pengolahan Air Ngagel I. Surabaya: Departement of Environmental Engineering ITS.

Brady, J.E. (1990). General chemistry: principles and structure. New York: Wiley.

Davison, A., Howard, G. , Stevens, M. Callan, P. Fewtrell, L. , Deere, D. and Bartram, J. (2005). Water safety plans managing drinking-water quality from catchment to consumer. Geneva : World Health Organisation.

Departemen Pekerjaan Umum (2007). Peraturan Menteri Pekerjaan Umum Nomor 18/PRT/M/2007 tentang Penyelenggaraan Pengembangan Sistem Penyediaan Air Minum. Jakarta: Departemen Pekerjaan Umum.

Egerton, A.J. (1996). Achieving reliableand cost effective water treatment, Water Science and Technology. Water science and technology, 33(2), 143-149.

Environmental Protection Agency (EPA) (2011). Water treatment manual: disinfection. Geneva: Environmental Protection Agency.

Farren, E.A. (2003) Reducing trihalomethane concentrations by using chloramines as a disinfectant. Worcester: Environmental Engineering Worcester Polytechnic Institute.

Fitria, N. (2009) Penilaian risiko pada instalasi pengolahan air limbah (IPAL) rumah sakit dengan metode failure mode and effect analysis (FMEA) : Studi kasus IPAL RSU Dr. Slamet Garut. Bandung: Environmental Management Technology ITB.

Gray, N.F. (2008). Drinking water quality: problems and solution. 2nd edition. Cambridge: Cambridge University Press.

Irawan, H. (2002). Sepuluh prinsip kepuasan pelanggan. Jakarta: Elex Media Komputindo.

Lindhe, A. (2010). Risk Assessment and Decision Support for Managing Drinking Water Systems. Gothenburg: Chalmers University of Technology. 